\title{
34. SURVEY OF POLLEN AND SPORES, DEEP SEA DRILLING PROJECT LEG $96^{1}$
}

\author{
Linda E. Heusser, Lamont-Doherty Geological Observatory²
}

\begin{abstract}
A preliminary palynological survey of 118 samples from the Mississippi Fan (Sites 615, 616, and 620) and from 2 intraslope basins (Sites 619 and 618) shows pollen in all samples. Reworked pollen is generally abundant, forming over $50 \%$ of the sum of pollen and reworked pollen. Concentration of nonreworked pollen is usually low (on the order of tens to hundreds of pollen grains per cubic centimeter wet sediment). Conifers, primarily Pinus, Picea, and Tsuga, dominate Pleistocene marine pollen spectra; significant percentages of Quercus are present in Holocene sediments and in sediments deposited during oxygen-isotope Stage 5.
\end{abstract}

\section{INTRODUCTION}

This chapter presents a preliminary survey of the pollen recovered from several sites drilled in the Gulf of Mexico during Deep Sea Drilling Project (DSDP) Leg 96 (Fig. 1), focusing on Sites 619 and 618, located in Pigmy and Orca basins, respectively. Previous Quaternary palynological studies in the Gulf of Mexico include analyses of the present distribution of pollen and spores by Darrel and Hart (1970) and Jendrzejewski and Hart (1978), and analyses of Quaternary sediments from piston cores by Elsik (1969), Heusser (1985), and Stanley $(1965,1966 a)$.

On Leg 96, we investigated the Mississippi Fan, a slope-rise depositional system in the Gulf of Mexico, and Orca and Pigmy basins, intraslope basins on the continental slope off Louisiana. The Mississippi Fan, one of the large deep-sea fans in modern oceans, extends about $600 \mathrm{~km}$ seaward from the present Mississippi River delta, covers an area greater than $290,000 \mathrm{~km}^{2}$ and has a volume of over $300,000 \mathrm{~km}^{3}$ of Quaternary sediments. The youngest of the seven individual fan lobes identified seismically on the Mississippi Fan was the main focus of DSDP Leg 96 (introductory chapter, this volume). This fan lobe can be divided into four major physiographic regions: (1) an upslope erosional submarine canyon; (2) an upper fan area at the base of the slope, characterized by a nearly filled erosional channel; (3) a middle fan area which is aggradational in character with a sinuous apical channel; and (4) a lower fan aggradational zone with active and abandoned channels (introductory chapter, this volume).

Pollen samples were studied from one site drilled in the lower fan (Site 615) and from two sites occupied on the middle fan (Sites 616 and 620) (Fig. 1). Pollen was analyzed in samples from two other sites drilled during Leg 96: Site 619 located in Pigmy Basin, a blocked-canyon intraslope basin; and Site 618 located in Orca Ba-

\footnotetext{
${ }^{1}$ Bouma, A. H., Coleman, J. M., Meyer, A. W., et al., Init. Repts. DSDP, 96: Washington (U.S. Govt. Printing Office).

2 Address: Lamont-Doherty Geological Observatory of Columbia University, Palisades, NY 10964.
}

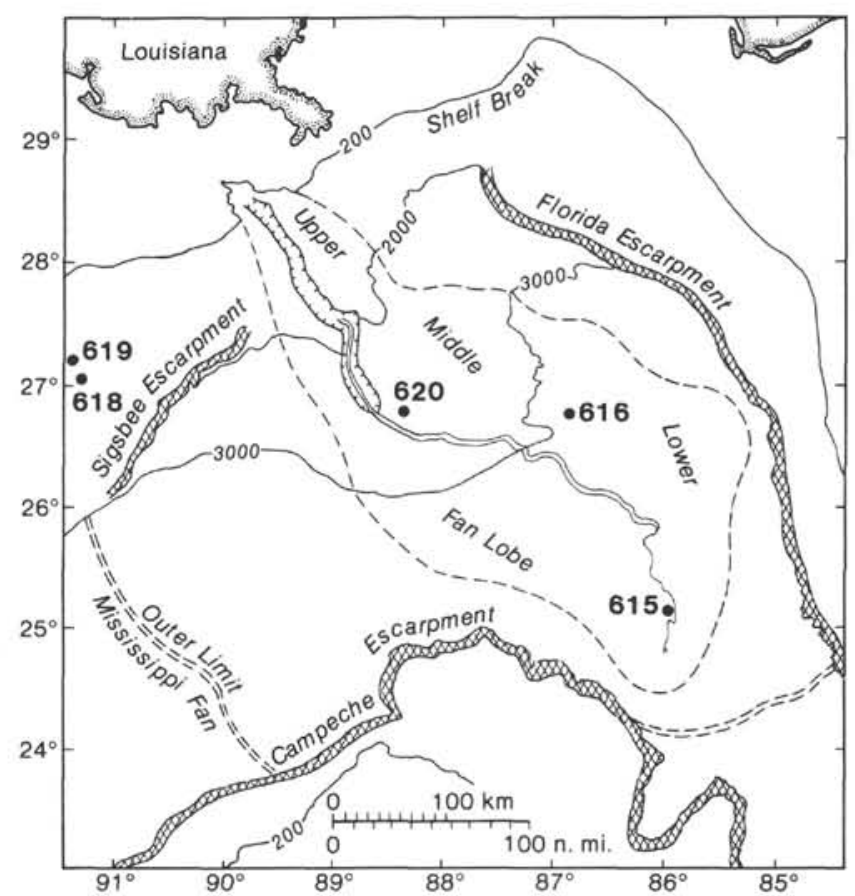

Figure 1. Location map of sites drilled during DSDP Leg 96 from which pollen samples were studied.

sin, an interdomal basin (Fig. 1). In Pigmy Basin, $208.7 \mathrm{~m}$ of Pleistocene calcareous clays and muds and silts and sands capped by a thin section of Holocene calcareous clay were recovered (Site 619 chapter, this volume). The site drilled in Orca Basin penetrated $\sim 18 \mathrm{~m}$ of Holocene and $\sim 63 \mathrm{~m}$ of Pleistocene muds and silts overlain by $\sim 12 \mathrm{~m}$ of displaced sediment interpreted as a massmovement deposit emplaced during the Holocene (Site 618 chapter, this volume).

\section{METHODS}

Samples were selected for pollen analysis by the shipboard scientific party from potentially productive intervals in cores taken from Holes $615,616,618,619$, and 620 . A total of 118 samples were processed for pollen analysis, using mechanical and chemical extraction techniques described in Heusser and Stock (1984). Sample size ranged from 7 to $23 \mathrm{~cm}^{3}$ wet sediment. Isolating pollen from the gumbo-like 
sediments required extensive sieving before and after chemical treatments to remove the large amounts of amorphous and particulate organic matter. The final residue, usually less than $0.05 \mathrm{~cm}^{3}$, was mounted in glycerin gelatin stained with Safranin 0, to aid in differentiating Quaternary from Tertiary and older grains (Stanley, 1966b). Reworked pollen (recycled or secondary pollen and spores derived from older, previously deposited sediments) was separated using differences in stain acceptance and morphologic criteria. Pollen identifications were usually done under oil immersion ( $\times 1000$ magnification). Pollen reference collections of Heusser were used in identification.

Pollen percentages were based on the sum of all contemporaneous (non-reworked) pollen grains in each sample. Percentages of pteridophyte spores were calculated using the sum of pollen plus spores as a numerical base. Percentages of other palynomorphs (i.e., reworked pollen, dinoflagellate cysts) were based on a total sum of all palynomorphs present. Pollen concentrations were calculated on the number of contemporaneous pollen grains per cubic centimeter of sediment.

\section{RESULTS}

All samples contain abundant organic matter, both structured plant debris and amorphous debris, as well as appreciable amounts of pollen which are usually dominated by reworked pollen and spores. Reworked Cretaceous and Tertiary pollen and spores identified in Pleistocene sediments of cores from Site 619 include Wodehouseia spinata, Aquilapollenites, Extratriporopollenites, Pterocarya, Proteacidites, Pistillipollenites, Cicatricosisporites, and Rugubivesiculites.

Samples from the intraslope basin sites (Site 618 and $619)$ proved the most useful for pollen analysis, as only 1 of the 66 samples studied from the Mississippi Fan (Sample 616-24-2, 30-32 cm) contains significant amounts of apparently contemporaneous (nonreworked) pollen. Even at the intraslope basin sites, concentration of nonreworked pollen is low (on the order of tens to hundreds of pollen grains per cubic centimeter wet sediment), although three samples from Site 619 (Samples 619-18-2, $38-39 \mathrm{~cm}, 619-19-3,58-62 \mathrm{~cm}$, and 619-22-2, 49-50 cm) contain $>1000$ grains $/ \mathrm{cm}^{3}$ (Table 1 ). Conifers, primarily Pinus, with lesser amounts of Picea, Tsuga, Abies, and representatives of the Cupressaceae and Taxodiaceae families are the most abundant Quaternary palynomorphs (Tables 1 and 2). Other trees and shrubs represented in Pleistocene pollen assemblages include Quercus, Corylus, Alnus, Betula, Liriodendron, Liquidambar, Fagus, Carya, Corylus, Celtis, Carpinus/Ostrya, Salix, Ulmus, Juglans, and Nyssa. Herbs, such as members of the Gramineae, Cyperaceae, Compositae, and Chenopodiaceae families, form up to $25 \%$ of contemporaneous pollen assemblages. Fern spores, principally polypodiaceous types, are usually present in low numbers, and spores of Sphagnum and the Lycopodiaceae are relatively rare.

\section{DISCUSSION}

Contrary to expectation, preliminary examination of samples from Sites $615,616,618,619$, and 620 reveals unexpectedly large amounts $(\sim 50 \%)$ of reworked palynomorphs in most samples-both from glacial and interglacial (Holocene) sediments (Table 3). Prior studies of pollen from cores in the Gulf of Mexico (Stanley, 1966a; Heusser, 1985) and from the northwest Atlantic Ocean (Heusser, unpublished data) and Bering Sea (Sancetta et al., 1985) show high percentages $(>50 \%)$ of reworked pollen in Pleistocene sediments, whereas reworked pollen is less important in Holocene sediments. The generally high percentages of reworked pollen in Holocene samples analyzed from Leg 96 suggest that dynamic mechanisms transport pollen eroded from Cretaceous and Tertiary continental and marine sediments even during interglacial times. Similar results were found in a study of pollen distribution in recent sediments from the continental margin of the northwest Atlantic Ocean (Heusser, unpublished data): although percentages of recycled pollen are usually low, $\sim 50 \%$ reworked pollen was identified in sediments deposited under the Western Boundary Undercurrent off eastern North America (Heusser and Balsam, 1985).

Pollen concentration (number of contemporaneous pollen grains/cubic centimeter wet sediment) is usually low $\left(<1000\right.$ grains $/ \mathrm{cm}^{3}$ ) (Tables 1 and 2 ), particularly compared with pollen concentration in shallow coastal muds of the Mississippi delta, which reach concentrations of $>10,000$ pollen grains $/ \mathrm{cm}^{3}$ (Darrell and Hart, 1970). The lower pollen concentration in samples analyzed from Leg 96 sediments is probably a function of winnowing by marine currents and dilution by other terrigenous components. In a broad survey of surficial sediments of the entire Gulf of Mexico, Jendrzejewski and Hart (1978) relate the absence of pollen in samples analyzed from the eastern half of the Gulf of Mexico to the effects of marine currents in the Gulf.

The relatively higher abundance of pollen in samples from the clay-dominated sediments of Site 619 (Samples 619-18-2, 38-39 cm, 619-19-3, 58-62 cm, and 619-22-2, $49-50 \mathrm{~cm}$ ) as compared with coarser-grained sediments may reflect the association of higher concentrations of pollen with fine-grained marine sediments, in contrast with lower concentrations in coarse-grained silts and sands. Results from a study of the present distribution of pollen and spores in the Gulf of Mexico, in Mississippi Sound and Bays, and in rivers from the southeastern United States show that the number of pollen grains per gram of sediment depends on sediment type, grain size, and preservation, with the largest number of pollen grains found in nearshore silty muds and lower quantities associated with sandy sediments (D. Englehardt, personal communication, 1984).

The composition of pollen assemblages in samples from DSDP sites on the Mississippi Fan and in Orca and Pigmy Basins reflects the source of the pollen (from vegetation in areas drained by the Mississippi River and by rivers flowing into the northern Gulf of Mexico as well as vegetation from the Gulf Coast) and fluviomarine sedimentation processes. Holocene pollen spectra (Table 1) include representatives of boreal conifer forests, grasslands, southeastern deciduous forests, and temperate forests. The prominent arboreal pollen types ( $\mathrm{Pi}$ nus, Picea, Cupressus-type, and Quercus) are similar to those found in Pleistocene pollen sequences from the northern Gulf of Mexico by Elsik (1969). However, Holocene samples from Site 619 (Table 1) differ from Holocene samples collected from piston Core EN32-PC6 taken previously from the same basin (Heusser, 1985), as oak (Quercus) percentages are lower in the Site 619 samples than in the EN32-PC6 samples. Pleistocene sam- 
Table 1. Initial survey of palynomorph distribution in samples from Site 619.

\begin{tabular}{|c|c|c|c|c|c|c|c|c|c|c|c|c|c|c|c|c|c|c|c|c|c|c|c|c|c|c|c|}
\hline $\begin{array}{c}\text { Sample } \\
\text { (interval in } \mathrm{cm} \text { ) }\end{array}$ & $\begin{array}{l}\text { Sub-bottom } \\
\text { depth } \\
\text { (m) }\end{array}$ & 1 & 2 & 3 & 4 & 5 & 6 & 7 & 8 & 9 & 10 & 11 & 12 & 13 & 14 & 15 & 16 & 17 & 18 & 19 & 20 & 21 & 22 & 23 & 24 & $\begin{array}{l}\text { Lithologic } \\
\text { units }^{\mathrm{a}}\end{array}$ & $\mathrm{Age}^{\mathrm{b}}$ \\
\hline $619-1-1,93-95$ & 1.94 & 32 & 18 & 1 & 7 & 1 & & 5 & 3 & 2 & 3 & 3 & 5 & & 2 & & & & 1 & & 4 & 5 & 4 & & 33 & Unit 1 & Holocene \\
\hline $619-1-2,93-95$ & 3.44 & 55 & 5 & & 8 & & & 3 & & 1 & 1 & 2 & 5 & & & & & & & & 2 & 7 & 6 & & 56 & Calcareous clays and muds & (Ericson Zone Z) \\
\hline $619-1-3,93-95$ & 4.94 & 51 & 3 & 1 & & & & 14 & 1 & & & 1 & 5 & & 1 & & 2 & 2 & & & 4 & 2 & 6 & 2 & 88 & & $--n-$ \\
\hline $619-1-4,93-95$ & 6.44 & 24 & 11 & 1 & 2 & & & 12 & 2 & 2 & 1 & 1 & 11 & & 1 & 1 & & 1 & & 1 & 6 & 5 & 4 & 3 & 276 & & ------ \\
\hline $619-1-5,93-95$ & 7.94 & 32 & 15 & 1 & 5 & & & 9 & 2 & & & 5 & 9 & & & & 1 & 1 & & & 1 & 9 & 7 & 2 & 125 & & \\
\hline $\begin{array}{l}619-1-6,93-95 \\
619-3-2,67-69\end{array}$ & $\begin{array}{r}9.44 \\
12.68\end{array}$ & $\begin{array}{r}5 \\
26\end{array}$ & $\begin{array}{l}26 \\
21\end{array}$ & & $\begin{array}{l}7 \\
6\end{array}$ & & & $\begin{array}{l}20 \\
12\end{array}$ & 3 & 2 & $\begin{array}{l}2 \\
3\end{array}$ & $\begin{array}{l}3 \\
5\end{array}$ & $\begin{array}{l}3 \\
7\end{array}$ & & & & & & & & $\begin{array}{l}6 \\
7\end{array}$ & $\begin{array}{r}10 \\
3\end{array}$ & $\begin{array}{r}14 \\
5\end{array}$ & 1 & $\begin{array}{l}64 \\
92\end{array}$ & & Pleistocene \\
\hline $619-3-4,67-69$ & 15.68 & 54 & 9 & & 11 & & & 4 & & 1 & 1 & & 23 & & & & 1 & & & & 3 & 4 & 9 & i & 82 & $\bar{U}_{\text {nit } \overline{I I}}--------$ & (Ericson Zone $\mathrm{Y}$ ) \\
\hline $619-3-6,67-69$ & 18.68 & 19 & 26 & & 5 & 1 & & 6 & 2 & 1 & 1 & 1 & & & & & 1 & & & & 9 & 7 & 6 & 1 & 33 & Calcareous clays and muds & \\
\hline $619-4-2,67-69$ & 22.38 & 18 & 11 & & 1 & & & 5 & 1 & & 1 & & & & & & & 1 & & & 2 & 2 & 1 & 3 & 45 & & \\
\hline $619-4-4,67-69$ & 25.38 & + & & & + & & & & & & & & & & & & & & & & & & & & 83 & & \\
\hline $619-5-2,67-69$ & 32.38 & + & & & & & & & & & & & & & & & & & & & & & & & 36 & & \\
\hline $619-5-4,67-69$ & 35.08 & + & & & + & & & & & & & & & & & & & & & & & & & & 6 & & \\
\hline $619-6-2,67-69$ & 41.78 & 35 & 23 & & 7 & 2 & & 4 & 1 & 1 & & & 2 & & & & & & & & 7 & 5 & 5 & 5 & 39 & & \\
\hline $619-6-4,67-69$ & 44.78 & 31 & 17 & & 15 & & & 3 & 2 & & 2 & 4 & 8 & & & & & & & & 8 & 6 & 3 & 2 & 240 & & \\
\hline $619-7-3,67-69$ & 52.98 & 42 & 10 & 1 & 9 & & & 4 & & 2 & 1 & & 1 & & & & & & & & 2 & 11 & 5 & & 220 & & \\
\hline $619-7-5,67-69$ & 55.98 & 51 & 1 & 1 & 24 & & & 7 & 1 & & & & 1 & & & & 2 & & & & 5 & 4 & 3 & 2 & 200 & & \\
\hline $619-8-2,67-69$ & 61.18 & 48 & 6 & & 13 & & & 4 & & 2 & & 2 & 1 & & & 1 & & & & & 3 & 12 & 5 & & 64 & & \\
\hline $619-8-4,67-69$ & 64.18 & 64 & & & 18 & & 3 & 5 & & & & & & & & & & & & & & 4 & 1 & & 192 & & \\
\hline $619-9-2,67-69$ & 70.88 & 58 & 4 & & 8 & & & 4 & 1 & 2 & & 1 & & 1 & 1 & & & & & & 5 & 7 & 6 & & 138 & $\bar{U}_{\text {nit }}^{\mathrm{III}}------\cdots$ & \\
\hline $619-10-2,88-90$ & 80.79 & 39 & 51 & 5 & & 10 & & & 9 & & & & 3 & 1 & & & & 2 & 1 & & 2 & 15 & 3 & & 400 & Calcareous clays and muds & \\
\hline $619-10-4,88-90$ & 78.39 & 38 & 6 & 1 & 6 & & & 9 & 4 & 1 & 1 & 1 & 2 & & 1 & & 1 & & & & 6 & 12 & 6 & 1 & 307 & & \\
\hline $619-11-2,67-68$ & 83.79 & 52 & 4 & 1 & 9 & 1 & 1 & 3 & & & & 2 & 3 & & & & & & & & 6 & 6 & 7 & 3 & 233 & & \\
\hline $619-12-2,67-68$ & 97.77 & 37 & 9 & & 9 & 1 & & 7 & 1 & & & 2 & 5 & & 1 & 1 & 1 & & & & 8 & 12 & 5 & & 160 & $\bar{U}_{\text {nit }} \bar{V}^{-}-------$ & \\
\hline $619-13-2,67-68$ & 109.38 & 36 & 10 & & 8 & 1 & & 13 & 1 & & & & 3 & & & 1 & & & & & 5 & 11 & 9 & 3 & 133 & Calcareous clays and muds & \\
\hline $619-13-4,67-68$ & 112.38 & 44 & 5 & & 10 & & & 8 & 1 & 1 & & 1 & 4 & 1 & 1 & & 2 & & & & 6 & 7 & 7 & 2 & 500 & & \\
\hline $619-14-1,77-78$ & 117.58 & 20 & 10 & & 4 & 1 & 1 & 13 & & i & 1 & i & 4 & & & & & 2 & & & 21 & 8 & 4 & 4 & 100 & Unit $\bar{v}--------$ & \\
\hline $619-15-2,67-69$ & 58 & 15 & 14 & 1 & 16 & & & 16 & & 1 & 1 & 1 & 1 & & 1 & & 3 & 1 & 1 & & 9 & 15 & 2 & 3 & 360 & Calcareous and noncalcareous & \\
\hline $619-15-3,65-67$ & 130.06 & 49 & 5 & & 8 & & & 14 & & & 1 & 3 & 1 & & 1 & & & 2 & & & 4 & 3 & 4 & 2 & 173 & clays and muds & \\
\hline $619-16-2,43-45$ & 137.94 & 30 & 9 & & 4 & & & 14 & & 2 & 1 & & 3 & & 1 & & & & & & 6 & 4 & 4 & 1 & 58 & & \\
\hline $619-16-4,43-45$ & 140.94 & 33 & 8 & 2 & 1 & & & 16 & & 1 & & & 9 & 1 & & & 1 & & & & 4 & 5 & 6 & 7 & 200 & & \\
\hline $619-17-2,32-34$ & 147.53 & 21 & 12 & 1 & 4 & 1 & & 15 & 1 & & 1 & & 8 & & & & & & 1 & 1 & 6 & 7 & 8 & 7 & 173 & & Pleistōecene- \\
\hline $619-17-4,32-34$ & 150.53 & 26 & 8 & & & $i$ & 1 & 18 & $i$ & & $i$ & 2 & & 1 & 1 & & 3 & & 1 & & 5 & 5 & 10 & 12 & 485 & & (Ericson Zone X) \\
\hline $619-18-2,38-49$ & 157.29 & 8 & 6 & 1 & 1 & & & 17 & & & $i$ & & 2 & 2 & & 1 & 2 & & $i$ & 1 & & 6 & 22 & 29 & 1000 & Unit $\overline{V I}--------$ & Pleistocene- \\
\hline $619-19-2,3-4$ & 166.64 & 45 & 4 & 3 & 2 & & 1 & 24 & 1 & 1 & 1 & 1 & 1 & & & & & 1 & & & 5 & 2 & 8 & 8 & 100 & Clays, muds, silts, and sands & (Ericson Zone X?) \\
\hline $619-19-3,58-62$ & 168.70 & 23 & 5 & & & & & 22 & 3 & 3 & 1 & 1 & 2 & & & & 2 & & & & 11 & 4 & 14 & 17 & 1100 & & \\
\hline $619-20-2,91-92$ & 177.12 & 21 & 4 & 1 & 1 & & & 27 & 2 & 2 & & 1 & 1 & & & & & 1 & & & 13 & 9 & 17 & 14 & 3000 & & \\
\hline $619-22-2,49-50$ & 189.30 & 29 & 3 & 2 & 2 & & & 14 & 1 & 1 & 2 & 1 & 4 & & & & 1 & & & & 7 & 4 & 11 & 13 & 800 & & \\
\hline
\end{tabular}

Note: Numbers are raw counts. In samples with very low pollen concentration, presence of a taxon is indicated by a plus sign. $1=$ Pinus, $2=$ inaperturate Cupressus type, $3=$ inaperturate Larix type, $4=$ Picea, $5=A$ Aies, $6=$ Tsuga, $7=$ Quercus, $8=$ Alnus, $9=$ Salix, $10=$ Myrica type, $11=$ Betula type, $12=$ Corylus type, $13=$ Acer, $14=$ Fagus, $15=$ Tilia, $16=$ Carya, $17=$ Ulmus, $18=$ Fraxinus, $19=$ Liquidambar, $20=$ Gramineae, $21=$ Cyperaceae, $22=$ Compositae, $23=$ Chenopodiaceae, $24=$ pollen concentration.

${ }_{b}^{a}$ From Site 619 chapter, this volume.

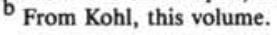


Table 2. Initial survey of palynomorph distribution in samples from Site 618.

\begin{tabular}{|c|c|c|c|c|c|c|c|c|c|c|c|c|c|c|c|c|c|c|c|c|c|c|c|c|c|c|c|}
\hline $\begin{array}{c}\text { Sample } \\
\text { (interval in } \mathrm{cm} \text { ) }\end{array}$ & $\begin{array}{l}\text { Sub-bottom } \\
\text { depth } \\
\text { (m) }\end{array}$ & 1 & 2 & 3 & 4 & 5 & 6 & 7 & 8 & 9 & 10 & 11 & 12 & 13 & 14 & 15 & 16 & 17 & 18 & 19 & 20 & 21 & 22 & 23 & 24 & $\begin{array}{l}\text { Lithologic } \\
\text { units }^{\mathrm{a}}\end{array}$ & $\mathrm{Age}^{\mathrm{a}}$ \\
\hline $618-1-2,110-111$ & 2.61 & 48 & 1 & & 13 & & & 11 & 1 & & & & 3 & & & & 3 & & & & 4 & 2 & 9 & & 350 & Unit I & Pleistocene \\
\hline $618-1-3,110-111$ & 4.11 & 51 & 3 & & 9 & & & 10 & & 1 & 1 & 4 & 2 & & & & 1 & 1 & 1 & & 5 & 3 & 3 & 2 & 450 & Muds and silts & (Ericson Zone Y) \\
\hline $618-1-4,110-111$ & 5.61 & 54 & 4 & 1 & 6 & 1 & & 8 & 2 & $\mathrm{i}$ & i & & 3 & & & 1 & 2 & $i$ & & & 6 & 4 & 5 & 1 & 100 & & \\
\hline $618-2-1,110-111$ & 7.64 & 54 & 7 & & 12 & & + & 6 & 2 & & & 1 & 5 & & & & $i$ & & 1 & & 7 & 6 & 6 & & 280 & & \\
\hline $618-2-2,113-114$ & 9.14 & 49 & 4 & & 17 & 2 & & 5 & & & & & 4 & & & & $i$ & & & & 3 & 3 & 9 & 1 & 122 & & \\
\hline $618-2-3,113-114$ & 10.64 & so & 1 & & 17 & $i$ & & 8 & & & & 1 & & & 1 & & $i$ & & 1 & & 2 & 7 & 4 & 2 & 400 & & \\
\hline $618-2-4,113-114$ & 12.14 & 24 & 5 & & 8 & & & 20 & & 1 & & 3 & 4 & & & & 4 & & & & 6 & 4 & 9 & 3 & 167 & & \\
\hline $618-6-1,74-77$ & 45.66 & 12 & 3 & & 1 & & & 1 & & & & & & & 1 & & & & & 2 & 2 & 1 & 2 & 1 & $<100$ & & \\
\hline $618-7-1,112-114$ & $\$ 2.03$ & + & & & + & & & + & & & 1 & & & & & & & & & $i$ & & & & & $<100$ & & \\
\hline $618-8-1,52-54$ & 57.43 & + & & & + & & & & & & $i$ & & & & & & & & & & & & & & $<100$ & & \\
\hline $618-9-1,42-44$ & 70.33 & + & & & + & & & & & & & & & & & & & & & & & & & & $<100$ & & \\
\hline $618-10-4,132-134$ & 80.23 & 16 & 2 & & 2 & & & 37 & 5 & & & 1 & 3 & & & & 2 & 1 & 2 & & 5 & 3 & 14 & 2 & 412 & & \\
\hline $618-11-1,28-30$ & 89.39 & 30 & 1 & 1 & 16 & & & 13 & 1 & & & $\mathrm{i}$ & 6 & & & & 2 & & & & 4 & 5 & 11 & 2 & 150 & & \\
\hline $618-11-2,28-30$ & 90.89 & 41 & 4 & & 14 & & & 8 & i & & 1 & $\mathrm{i}$ & 5 & & & & $i$ & & & & 3 & 9 & 8 & 4 & 129 & & \\
\hline
\end{tabular}

Note: In samples with very low pollen concentration, presence of a taxon is indicated by a plus sign. $1=$ Pinus, $2=$ inaperturate Cupressus type, $3=$ inaperturate Larix type, $4=$ Picea, $5=$ Abies, $6=$ Tsuga, $7=$ Quercus, $8=$ Alnus, $9=$ Salix, $10=$ Myrica type, $11=$ Betula type, $12=$ Corylus type, $13=$ Acer, $14=$ Fagus, $15=$ Tilia, $16=$ Carya, $17=$ Ulmus, $18=$ Nussa, $19=$ Liquidambar, $20=$ Gramineae, $21=$

a Cyperaceac, $22=$ Compositae, $23=$ Chenopodiaceae, $24=$ pollen concentration.

Table 3. Ratio of reworked to nonreworked pollen in selected samples from Leg 96.

\begin{tabular}{lrc}
\hline $\begin{array}{c}\text { Sample } \\
\text { (interval in cm) }\end{array}$ & $\begin{array}{c}\text { Sub-bottom } \\
\text { depth } \\
\text { (m) }\end{array}$ & $\begin{array}{c}\text { Ratio reworked/ } \\
\text { nonreworked } \\
\text { pollen }\end{array}$ \\
\hline $615-1-2,59-61$ & 2.10 & 0.04 \\
$615-2-1,93-96$ & 3.55 & 0.25 \\
$615-2-2,63-65$ & 4.74 & 0.11 \\
$615-2-3,65-66$ & 6.26 & 0.10 \\
$615-2-6,116-117$ & 11.27 & 0.25 \\
$615-3-1,10-12$ & 12.21 & 1.00 \\
$615-5-5,90-92$ & 36.51 & 1.00 \\
$615-5-6,20-22$ & 37.31 & 0.36 \\
$615-22-2,90-92$ & 193.11 & 1.70 \\
$615-22-3,90-92$ & 194.61 & 1.70 \\
$618-1-2,110-111$ & 2.61 & 0.90 \\
$618-1-3,110-111$ & 4.11 & 0.20 \\
$618-6-1,74-77$ & 45.66 & 2.00 \\
& & 6.00 \\
$619-1-5,93-95$ & 7.94 & 5.00 \\
$619-1-6,93-95$ & 9.44 & 4.90 \\
$619-3-2,67-69$ & 12.68 & 6.00 \\
$619-3-6,67-69$ & 18.68 & 16.00 \\
$619-16-2,43-45$ & 137.94 & \\
\hline
\end{tabular}

ples in both cores (EN32-PC6 and Site 619) are similar, containing higher quantities of boreal conifer pollen (including Picea, Abies, and Tsuga) than Holocene sediments.

Comparing the preliminary pollen data (Table 1, Fig. 2) with the detailed isotope chronostratigraphy and carbonate record from Site 619 (Williams and Kohl, this volume) is not entirely satisfactory because of the large difference in sampling frequency ( 41 pollen samples versus 190 isotope samples) between the two data sets. However, the general trends seen in the relative frequencies of pine, boreal conifers (spruce, hemlock, and fir), and oak appear conformable with inferred regional vegetation and climate changes during isotope Stages 1 through 5. Conifer pollen (associated with boreal environments) is more abundant in sediments deposited during the last glacial period, whereas oak pollen (characteristic of temperate and deciduous forests) is more abundant in interglacial sediments.

Unexpectedly, pollen signatures of meltwater events (i.e., pollen spectra characterized by a Quercus-domi-

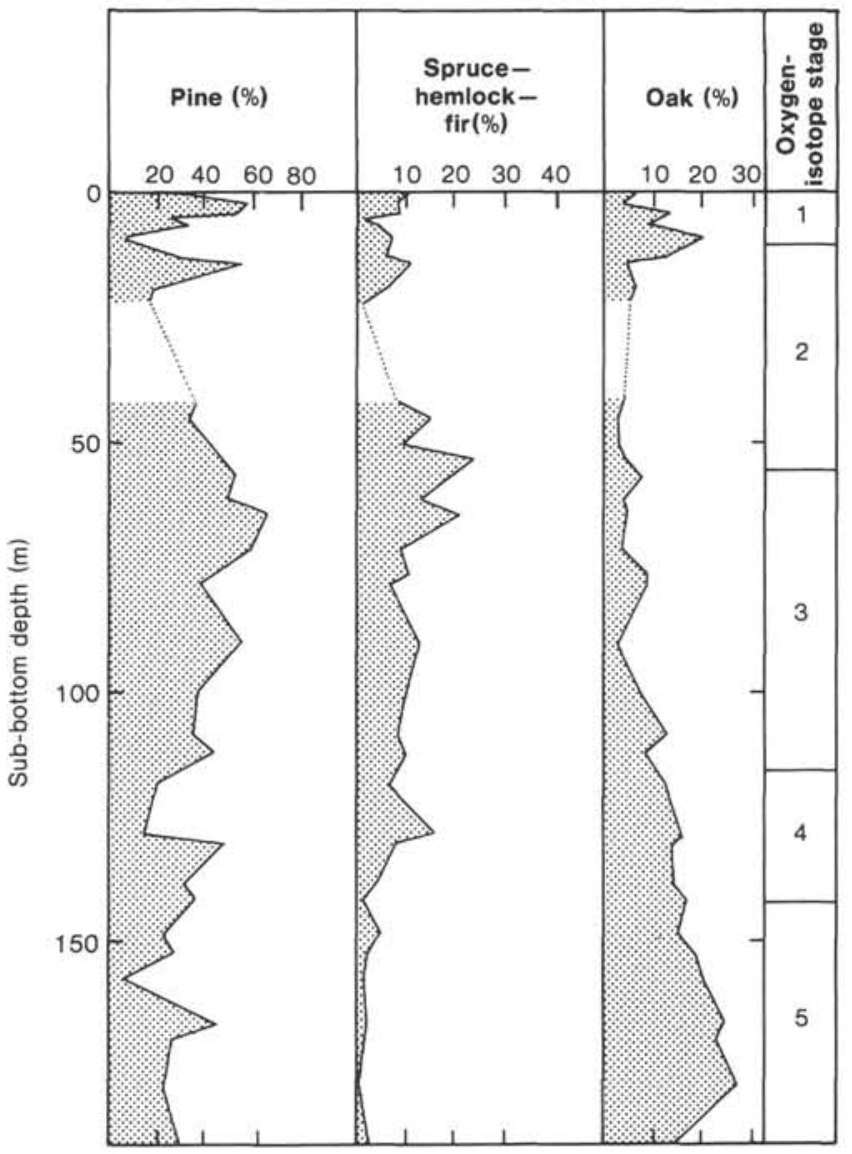

Figure 2. Relative frequency of selected pollen taxa from Site 619, Pigmy Basin. Pollen types are pine (Pinus), spruce (Picea spp.), hemlock (Tsuga canadensis), fir (Abies spp.), and oak (Quercus spp). Oxygen-isotope stratigraphy is from Williams and Kohl (this volume).

nated deciduous tree pollen assemblage and a spike in pollen concentration; Heusser, 1985) are recorded in only three samples from Pigmy Basin (Samples 619-18-2, $38-39 \mathrm{~cm}, 619-19-3,58-62 \mathrm{~cm}$, and 619-20-2, 91-92 cm, Table 2). However, it should be noted that none of the intervals interpreted as meltwater spikes in the oxygenisotope record by Williams and Kohl (this volume) were 
analyzed for pollen, and that oxygen-isotope analyses are not available from the levels containing the pollen meltwater signatures. The brevity of the meltwater events (on the order of thousands of years) and the wide interval between pollen samples in Site 619 therefore probably precluded identification of meltwater events in our pollen study.

\section{ACKNOWLEDGMENTS}

I would like to acknowledge the assistance of E. Stock in processing the samples and thank A. Meyer for editorial assistance. D. Habib and an anonymous reviewer reviewed an earlier version of this manuscript.

\section{REFERENCES}

Darrell, J. A., and Hart, G. F., 1970. Environmental determinations using absolute miospore frequency, Mississippi River delta. Geol. Soc. Am. Bull., 81:2513-2518.

Elsik, W. C., 1969. Late Neogene palynomorph diagrams, northern Gulf of Mexico. Trans. Gulf Coast Assoc. Geol. Soc., XIX:509528.

Heusser, L. E., 1985. North American Quaternary marine palynology. In Bryant, Jr., V. M., and Holloway, R. G. (Eds.), Pollen Records of Late Quaternary North American Sediments: Dallas (American Association of Stratigraphic Palynologists), pp. 385-403.

Heusser, L. E., and Balsam, W. L., 1985. Pollen sedimentation in the northwest Atlantic: effects of the Western Boundary Undercurrent. Mar. Geol., 69:149-153.

Heusser, L. E., and Stock, C. E., 1984. Preparation techniques for concentrating pollen from marine sediments with low pollen density. Palynology, 8:225-227.

Jendrzejewski, J. P., and Hart, G. F., 1978. Distribution of siliceous microfossil in surficial bottom sediments of the Gulf of Mexico. Palynology, 2:159-166.

Sancetta, C., Heusser, L., Labeyrie, L., Naidu, A. S., and Robinson, S. W., 1985. Wisconsin-Holocene paleoenvironment of the Bering Sea: evidence from diatoms, pollen, oxygen isotopes and clay minerals. Mar. Geol., 62:55-68.

Stanley, E. A., 1965. Use of reworked pollen and spores for determining the Pleistocene-Recent and the intra-Pleistocene boundaries. Nature, 206:289-291.

1966a. The application of palynology to oceanology with reference to the northwestern Atlantic. Deep-Sea Res., 13:921-939. 1966b. The problem of reworked pollen and spores in marine sediments. Mar. Geol., 4:397-408.

Date of Initial Receipt: 4 February 1985

Date of Acceptance: 5 September 1985 